\title{
FAKTOR-FAKTOR YANG BERPENGARUH TERHADAP TINGKAT KEMANDIRIAN PETANI KEDELAI DI KECAMATAN JATIWARAS KABUPATEN TASIKMALAYA
}

\section{FACTORS AFFECTING THE INDEPENDENCE OF SOYBEAN FARMERS IN JATIWARAS, TASIKMALAYA DISTRICT}

\author{
Ivan Sayid Nurahman*, Tiktiek Kurniawati \\ Fakultas Pertanian, Universitas Galuh \\ *E-mail: v.sayid9@gmail.com \\ (Diterima 02-11-2020; Disetujui 29-12-2020)
}

\begin{abstract}
ABSTRAK
Perkembangan produksi kedelai dalam negeri yang cenderung lambat menyebabkan permintaan kedelai tidak dapat terpenuhi setiap tahunnya meski berbagai program pemerintah telah digulirkan. Ketidakmampuan kedelai lokal untuk memenuhi kebutuhan kedelai di dalam negeri menyebabkan ketergantungan pada kedelai impor. Penggunaan metode pemberdayaan petani yang baik dan tepat menjadi sebuah urgensi, sehingga petani menjadi berdaya dan memiliki kemandirian. Penelitian ini bertujuan untuk mengetahui tingkat kemandirian petani kedelai dan menganalisis faktor-faktor apa saja yang mempengaruhi tingkat kemandirian petani di Kecamatan Jatiwaras Kabupaten Tasikmalaya. Penelitian dilaksanakan dengan menggunakan metode survei di Kecamatan Jatiwaras, Kabupaten Tasikmalaya yang merupakan daerah pengembangan kedelai potensial di Jawa Barat dengan mengambil sampel sebanyak 127 petani kedelai menggunakan simple random sampling. Data yang dikumpulkan dalam penelitian ini terdiri atas data primer dan data sekunder. Analisis data dilakukan dengan menggunakan analisis deskriptif dan analisis regresi linier berganda. Hasil penelitian menunjukkan bahwa: (1) tingkat kemandirian petani kedelai di Kecamatan Jatiwaras termasuk kategori sedang, (2) motivasi, kemampuan, lingkungan sosial budaya, kinerja penyuluhan, keberdayaan, dan partisipasi berpengaruh signifikan terhadap kemandirian petani kedelai, sedangkan kedinamisan tidak berpengaruh signifikan.
\end{abstract}

Kata kunci: faktor-faktor, kemandirian, petani, kedelai

\begin{abstract}
The development of domestic soybean production which tends to be slow causes the demand for soybeans to be unable to be fulfilled every year even though various government programs have been rolled out. The inability of local soybeans to meet domestic demand for soybeans causes dependence on imported soybeans. The use of good and appropriate farmer empowerment methods becomes an urgency, so that farmers become empowered and have independence. This study aims to determine the level of independence of soybean farmers and analyze the factors that affect the level of independence of farmers in Jatiwaras District, Tasikmalaya Regency. The research will be carried out using a survey method in Jatiwaras District, Tasikmalaya Regency which is a potential soybean development area in West Java by taking a sample of 127 soybean farmers using simple random sampling. The data collected in this study consisted of secondary data and primary data. The data analysis method used in this research is descriptive analysis and multiple linear regression analysis. The results showed that (1) the level of independence of soybean farmers in Jatiwaras District was in the moderate category, (2) motivation, ability, socio-cultural environment, extension performance, empowerment, and participation had a significant effect on the independence of soybean farmers, while dynamism had no significant effect.
\end{abstract}

Keywords: factors, independence, farmers, soybeans 


\section{PENDAHULUAN}

Kedelai merupakan komoditas pangan dengan kandungan protein nabati tinggi dan telah digunakan sebagai bahan baku produk olahan seperti susu kedelai, tempe, tahu, kecap, dan berbagai makanan ringan lainnya. Peningkatan jumlah penduduk dan kesadaran akan pentingnya hidup sehat berdampak pada meningkatnya kebutuhan kedelai dari tahun ke tahun (Krisnawati, 2017).

Kementan (2019) mengungkapkan bahwa meningkatnya kebutuhan kedelai dalam negeri tidak dapat diimbangi oleh produksi kedelai dalam negeri (Gambar 1), sehingga kebutuhan kedelai dipenuhi dengan impor.

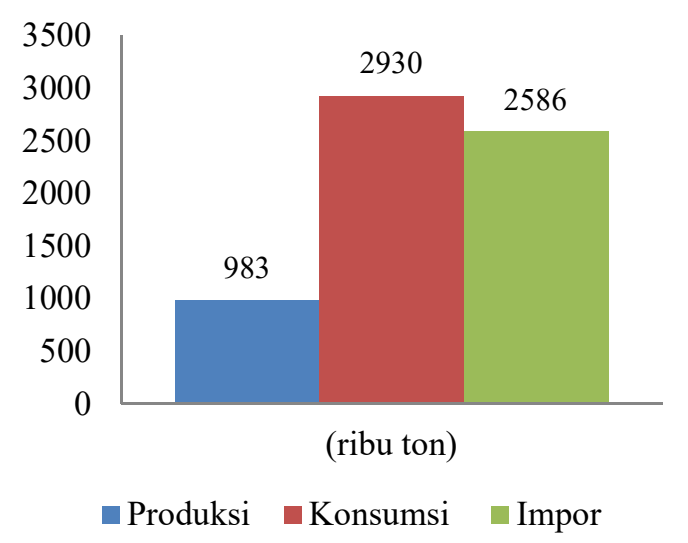

\section{Gambar 1. Produksi dan Konsumsi Kedelai Nasional Tahun 2018}

Kondisi ini dikhawatirkan akan meningkatkan ketergantungan terhadap impor kedelai. Seperti yang dikemukakan Hasan dkk (2015) bahwa kesenjangan antara produksi kedelai dan permintaan kedelai di Indonesia selama puluhan tahun telah memicu ketergantungan pada kedelai impor. Ketergantungan impor yang tinggi terjadi karena petani untuk menjalankan usahatani kedelai dihadapkan dengan berbagai risiko dan ketidakpastian. Salah satu diantaranya adalah tingginya risiko serangan hama penyakit dan harga kedelai domestik yang cenderung mahal mengakibatkan kedelai impor lebih diminati oleh masyarakat.

Upaya pemberdayaan petani dirasa sangatlah penting untuk merubah paradigma dan perilaku petani terhadap komoditas kedelai. Wulanjari dan Setiani (2018) menyebutkan bahwa pemberdayaan harus mampu merubah perilaku dan menyentuh semua aspek yang dibutuhkan masyarakat (petani). Diharapkan melalui proses pemberdayaan petani akan lebih termotivasi untuk terus melaksanakan usahatani kedelai secara mandiri dan berkelanjutan.

Kabupaten Tasikmalaya merupakan sentra pengembangan produksi kedelai potensial di Jawa Barat. Potensi tersebut sangat mendukung dalam upaya pencapaian swasembada kedelai, dimana di wilayah Kabupaten Tasikmalaya bagian selatan terdapat sumber daya lahan yang masih belum teroptimalkan 
diantaranya banyak lahan-lahan yang sudah tidak produktif, salah satu diantaranya adalah lahan eks perkebunan karet yang berlokasi di Kecamatan Jatiwaras.

Berdasarkan uraian di atas, maka penelitian ini bertujuan untuk mengetahui tingkat kemandirian petani kedelai dan faktor-faktor yang mempengaruhi kemandirian petani kedelai di Kecamatan Jatiwaras Kabupaten Tasikmalaya.

\section{METODE PENELITIAN}

Penelitian ini dilakukan dengan metode survei yang bersifat eksplanasi yaitu menjelaskan gejala perilaku petani dan keterkaitan antar variabel penelitian (Indraningsih, 2013; Sumarlan, 2012). Kecamatan Jatiwaras dipilih secara sengaja (purposive sampling) sebagai sampel wilayah dengan pertimbangan merupakan daerah pengembangan kedelai potensial di Jawa Barat. Pengambilan sampel penelitian menggunakan teknik penarikan sampel acak sederhana (simple random sampling) terhadap seluruh petani kedelai di Kecamatan Jatiwaras yang termasuk dalam populasi penelitian. Jumlah sampel penelitian adalah 127 orang petani kedelai, yang diperoleh dari hasil penghitungan sampel penelitian menggunakan rumus Slovin sebagai berikut (Mun'im, 2012).

$n=\frac{N}{1 . N e^{2}}$

Dimana:

$\mathrm{n}=$ Ukuran sampel

$\mathrm{N}=$ Populasi

$\mathrm{e}=$ margin of error (pada penelitian ini ditetapkan 0,05 dengan tingkat kepercayaan 95\%)

Data yang dikumpulkan dalam penelitian ini terdiri atas data primer dan data sekunder. Data primer diperoleh dari pengamatan langsung terhadap obyek penelitian dan survei menggunakan kuesioner. Format jawaban dalam kuesioner menggunakan skala Likert dengan lima alternatif jawaban. Data sekunder diperoleh dari penelusuran berbagai hasil penelitian, studi pustaka, laporan dan dokumen dari berbagai instansi yang berkaitan dengan penelitian.

Tingkat kemandirian petani kedelai diukur dengan menggunakan indikator kemandirian intelektual, kemandirian material, dan kemandirian pembinaan. Skor total masing-masing responden dikategorikan menjadi tiga, yaitu rendah, sedang dan tinggi; yang kemudian dianalisis secara deskriptif. Analisis deskriptif adalah analisis yang digolongkan sebagai upaya untuk menentukan, menggambarkan atau mengidentifikasi apa yang ada, berupa 
sintesis dan tidak menganalisis (Ethridge, 2004). Faktor-faktor yang diduga berpengaruh terhadap kemadirian petani kedelai dalam penelitian ini diperoleh dari hasil studi pustaka terhadap hasil penelitian terdahulu, diantaranya motivasi, kemampuan, kedinamisan, keberdayaan, lingkungan sosial budaya, kinerja penyuluhan, dan partisipasi. Variabel-variabel tersebut kemudian dianalisis menggunakan model persamaan regresi linier berganda sebagai berikut:

$\mathrm{Y}=\mathrm{a}+\mathrm{b}_{1} \mathrm{X}_{1}+\mathrm{b}_{2} \mathrm{X}_{2}+\mathrm{b}_{3} \mathrm{X}_{3}+\mathrm{b}_{4} \mathrm{X}_{4}+$ $\mathrm{b}_{5} \mathrm{X}_{5}+\mathrm{b}_{6} \mathrm{X}_{6}+\mathrm{b}_{7} \mathrm{X}_{7}+\mathrm{e}$

Dimana:

$\mathrm{Y}=$ Kemandirian petani

$\mathrm{X} 1=$ Motivasi

$\mathrm{X} 2$ = Kemampuan

$\mathrm{X} 3$ = Kedinamisan

X4 = Keberdayaan

X5 = Lingkungan sosial budaya

$\mathrm{X} 6$ = Kinerja penyuluhan

$\mathrm{X} 7$ = Partisipasi

$\mathrm{B}=$ Koefisien regresi

\section{HASIL DAN PEMBAHASAN}

\section{Tingkat Kemandirian Petani Kedelai}

Selama ini pembangunan pertanian di Indonesia hanya terfokus pada pembangunan usahatani dengan sasaran utama peningkatan produksi. Padahal pendekatan pembangunan yang selama ini dirasa sangat sentralistik (terpusat) dan top down. Diperlukan adanya perubahan paradigma pembangunan pertanian dari konvensional ke paradigma baru, yakni pembangunan berkelanjutan (Mugniesyah, 2006).

$$
\text { Paradigma baru tersebut }
$$

memandang petani sebagai prioritas dimana mereka mempunyai pengetahuan dan kearifan sendiri (indigenous knowledge), sehingga pendekatan pembangunan lebih memperhatikan pengetahuan dan pengalaman petani (bottom up). Budiman dan Sadono (2010) menyebutkan bahwa pemerintah melalui Kementerian Pertanian telah berupaya untuk mencapai pembangunan pertanian Indonesia menuju lebih maju salah satunya melalui perbaikan sistem penyuluhan (Undang-Undang Sistem Penyuluhan Pertanian, Perikanan, dan Kehutanan (SP3K) No. 16 Tahun 2006). Revitalisasi pertanian tersebut dilakukan dengan berbagai langkah, salah satunya adalah dengan peningkatan kemampuan petani dan penguatan lembaga pendukungnya.

Diharapkan dengan disahkannya undang-undang tersebut para petani mampu mandiri dan tangguh dalam melaksanakan usahatani, dan tidak lagi mengharapkan subsidi dan proteksi dari pemerintah. Kemandirian petani untuk mewujudkan ketangguhan berusahatani 
adalah suatu kondisi yang dapat ditumbuhkan melalui proses pemberdayaan (empowerment). Tingkat kemandirian petani kedelai dalam penelitian ini diukur dengan menggunakan indikator menurut Marliati et al (2010), yakni kemandirian intelektual, kemandirian material, dan kemandirian pembinaan atau pengembangan diri.

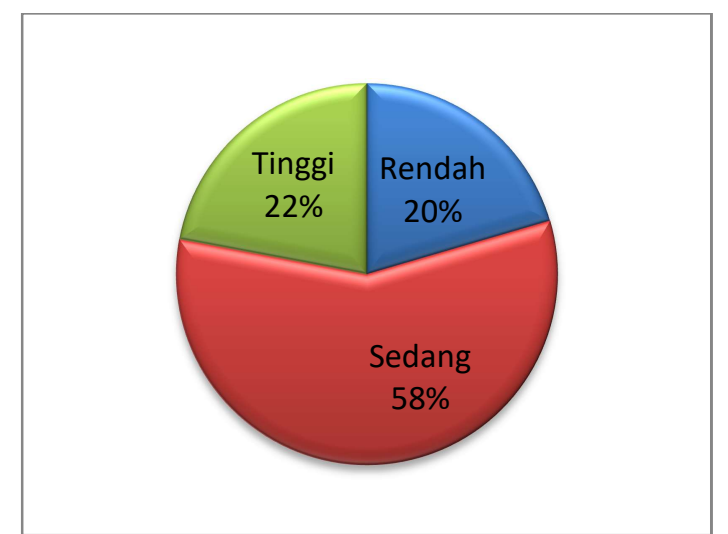

\section{Gambar 2. Persentase Tingkat Kemandirian Petani Kedelai di Kecamatan Jatiwaras}

Hasil penelitian menunjukan bahwa tingkat kemandirian petani kedelai di Kecamatan Jatiwaras termasuk kategori sedang (58 persen) (Gambar 2). Artinya, petani kedelai di Kecamatan Jatiwaras dikatakan belum bisa menjalankan usahatani kedelai secara mandiri. Hal tersebut tidak lain disebabkan oleh pergeseran perilaku petani kedelai di Kecamatan Jatiwaras yang tadinya melakukan usahatani kedelai tanpa bantuan pemerintah, sekarang mereka menjadi ketergantungan akan bantuan sarana produksi kedelai dari pemerintah. Tentunya hal tersebut membuat tujuan pemerintah yang tadinya bertujuan memberikan insentif bagi petani kedelai berubah menjadi disinsentif bagi petani kedelai di Kecamatan Jatiwaras. Temuan lapangan menunjukkan bahwa ketergantungan petani bukan tidak beralasan, melainkan karena komoditas kedelai saat ini dipandang bernilai ekonomi rendah jika dibandingkan komoditas pangan lainnya seperti padi dan jagung.

Sejalan dengan yang dikemukakan Sudaryanto dan Swastika (2013) bahwa faktor harga kedelai yang membuat petani enggan menanam kedelai. Insentif saprodi kedelai dari pemerintah justru malah menjadi disinsentif bagi petani karena tidak diimbangi dengan kebijakan harga, dimana harga riil kedelai impor jauh lebih murah dari pada kedelai produksi dalam negeri. Selama harga kedelai impor lebih rendah, maka arus impor akan makin deras, sehingga harga kedelai produksi dalam negeri akan makin turun. Perlu upaya-upaya untuk mengatasi permasalahan di atas agar tidak terus berlanjut dan membuat petani ketergantungan terhadap bantuan pemerintah dalam pengembangan 
kedelai. Salah satunya adalah dengan pengendalian impor dan pengamanan pasar dalam negeri yang harus ditingkatkan. Sehingga dengan demikian petani akan kembali bergairah dalam mengembangkan kedelai tanpa mengandalkan bantuan pemerintah (mandiri).

\section{Kemandirian Intelektual}

Kemandirian intelektual petani dalam melaksanakan usahatani kedelai pada penelitian ini diartikan sebagai kemampuan petani memanfaatkan lahan, waktu, dan peluang untuk meningkatkan produktivitas dan pendapatan, kemampuan membuat keputusan yang rasional, kemampuan memecahkan masalah, dan lain-lain. Hasil menunjukkan bahwa kemandirian intelektual petani kedelai di Kecamatan Jatiwaras termasuk kategori tinggi (43 persen) (Gambar 3). Artinya petani kedelai di Kecamatan Jatiwaras mampu secara mandiri memanfaatkan peluang dan potensi yang ada berdasarkan rasionalitasnya (pertimbangan baik dan buruk) dalam menjalankan usahatani kedelai.

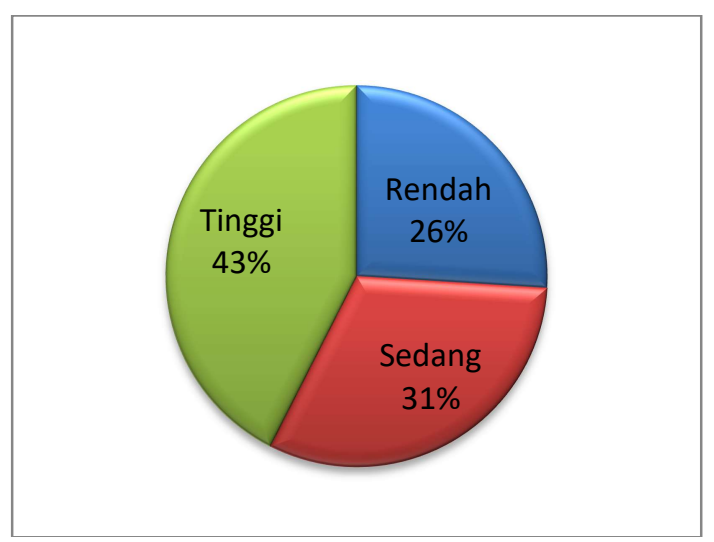

\section{Gambar 3. Persentase Tingkat Kemandirian Intelektual Petani Kedelai di Kecamatan Jatiwaras}

Mereka mengkolaborasikan antara tacit-exlicit knowledge dalam menjalankan usahatani kedelai untuk mendapatkan produksi dan pendapatan yang lebih tinggi. Hal tersebut menurut petani adalah sebuah konformitas atau bentuk kepatuhan terhadap budaya lokal serta kepatuhan terhadap pemerintah dalam upaya peningkatan produksi kedelai. Sejalan dengan yang dikemukakan Marwoto dkk (2012) bahwa pemanfaatan setiap potensi untuk pengembangan kedelai seperti lahan non produktif, pengetahuan lokal, dan upayaupaya pengoptimalan pendapatan petani dari komoditas kedelai sangat penting untuk keberlanjutan usahatani kedelai.

\section{Kemandirian Material}

Kemandirian material petani dalam melaksanakan usahatani kedelai pada penelitian ini diartikan sebagai 
kemampuan berinvestasi untuk pengembangan usaha dan mampu memenuhi kebutuhan-kebutuhan dasar melalui pendapatan usahatani kedelai. Hasil menunjukkan bahwa kemandirian material petani kedelai di Kecamatan Jatiwaras termasuk kategori rendah (47 persen) (Gambar 4). Artinya petani kedelai di Kecamatan Jatiwaras belum mampu secara mandiri untuk mengembangkan usahataninya. Sebagian besar petani kedelai di Kecamatan Jatiwaras cenderung menggunakan input minimal dalam menjalankan usahatani kedelai.

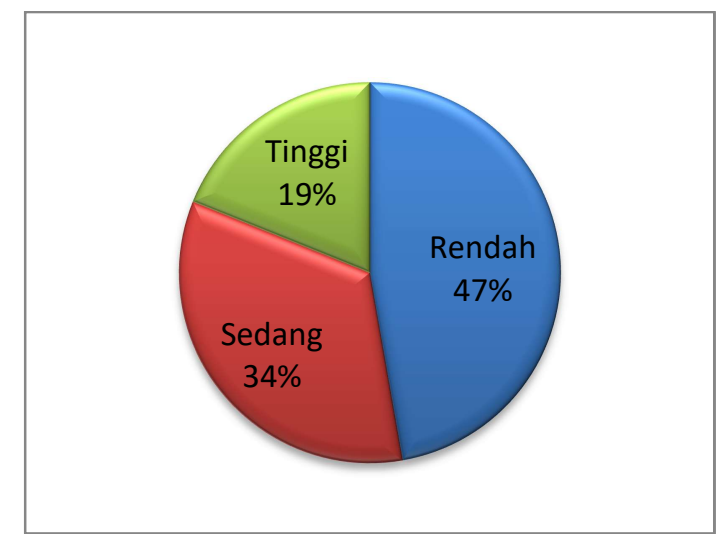

\section{Gambar 4. Persentase Tingkat Kemandirian Material Petani Kedelai di Kecamatan Jatiwaras}

Beberapa tahun terakhir setelah adanya program bantuan sarana produksi untuk usahatani kedelai dari pemerintah, malah membuat petani terlena. Sehingga yang tadinya bantuan tersebut sebagai insentif bagi petani, malah menjadi disinsentif karena tidak merangsang petani untuk lebih mandiri dalam menjalankan usahatani kedelai. Sejalan dengan yang dikemukakan Departemen Pengembangan Akses Keuangan dan UMKM Bank Indonesia (2013) bahwa jangan sampai bantuan sarana produksi kedelai yang tadinya bertujuan sebagai stimulus bagi petani malah membuat petani ketergantungan terhadap bantuan tersebut. Oleh karena itu, peran pendamping atau penyuluh sangat penting dalam upaya pencapaian tujuan yang diharapkan, yakni swasembada kedelai.

\section{Kemandirian Pembinaan}

Kemandirian pembinaan atau pengembangan diri petani dalam melaksanakan usahatani kedelai pada penelitian ini diartikan sebagai kemampuan memanfaatkan informasi, media, tenaga penyuluh, dan pelatihan serta kemampuan berbagi ilmu dengan sesama petani kedelai. Hasil menunjukkan bahwa kemandirian pembinaan petani kedelai di Kecamatan Jatiwaras termasuk kategori sedang (45 persen) (Gambar 5). Artinya petani kedelai di Kecamatan Jatiwaras belum sepenuhnya mampu secara mandiri memanfaatkan media dan informasi khususnya dunia digital. Hal tersebut 
disebabkan oleh rendahnya tingkat pendidikan petani yang relatif rendah dan umur petani yang sebagian besar tua atau menjelang tidak produktif. Masalah tersebut menjadi kendala ketika akan menerima informasi inovasi teknologi yang saat ini sudah disebar melalui dunia digital (digital extension)

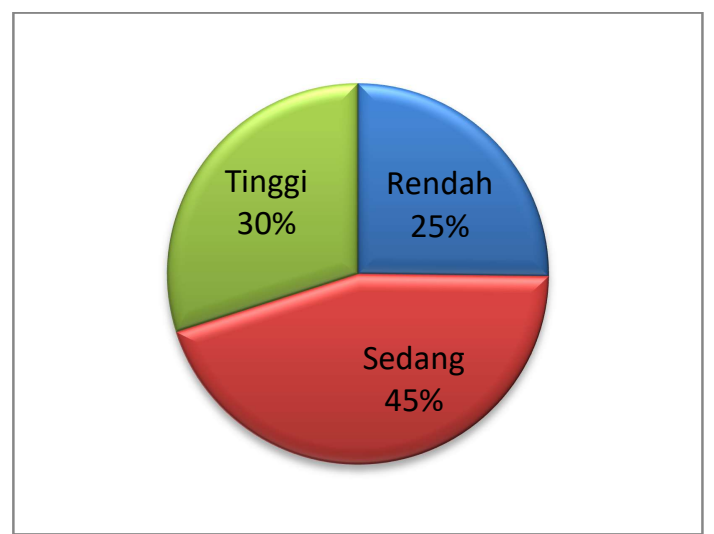

Gambar 5. Persentase Tingkat Kemandirian Pembinaan Petani Kedelai di Kecamatan Jatiwaras

Apriantono (2006) menyebutkan bahwa saat ini teknologi digital merupakan sebuah keniscayaan yang tidak dapat dibendung dan tidak pula dipungkiri kemajuannya. Namun, masalah yang dihadapi petani saat ini adalah penguasaan informasi yang masih sangat lemah. Padahal, informasi merupakan aspek penting bagi pembangunan sosial ekonomi di pedesaan dan berpengaruh terhadap penerimaan gagasan baru dan penting untuk mengintegrasikan diri dengan dunia luar.

Faktor-faktor yang Berpengaruh Terhadap Tingkat Kemandirian Petani Kedelai

Pendugaan parameter faktor-faktor yang berpengaruh terhadap tingkat kemandirian petani kedelai dilakukan dengan menggunakan software SPSS 20. Hasil pendugaan parameter selengkapnya dapat dilihat pada Tabel 1.

Tabel 1. Faktor-faktor yang Berpengaruh Terhadap Kemandirian Petani Kedelai

\begin{tabular}{|l|c|c|c|}
\hline \multicolumn{1}{|c|}{ Variabel } & Nilai Parameter & t-hit & Sig. \\
\hline Konstanta & $-1,150$ & $-5,181$ & 0,000 \\
\hline Motivasi & 0,166 & $5,723^{* * *}$ & 0,000 \\
\hline Kemampuan & 0,191 & $7,389^{* * *}$ & 0,000 \\
\hline Kedinamisan & 0,012 & 0,266 & 0,791 \\
\hline Keberdayaan & 0,146 & $6,037^{* * *}$ & 0,000 \\
\hline LingkSosBud & 0,171 & $7,171^{* * *}$ & 0,000 \\
\hline Kinerja Penyuluhan & 0,164 & $6,849^{* * *}$ & 0,000 \\
\hline Partisipasi & 0,170 & $7,616^{* * *}$ & 0,000 \\
\hline $\mathrm{R} \quad=0,843$ & & \\
$\mathrm{R}^{2} \quad=0,710$ & & \\
F-hit $=41,670^{* * *}$ &
\end{tabular}

Sumber: Analisis Data Primer, 2020

$*,{ }^{*}, * * *$ signifikan pada $\alpha 0,01 ; 0,05 ; 0,10$ 
Nilai koefisien determinasi ( $\left.\mathrm{R}_{2}\right)$ sebesar 0,710 (Tabel 1) menunjukkan bahwa tingkat kemandirian petani kedelai dapat dijelaskan sebesar $71 \%$ oleh variabel yang dimasukkan ke dalam model, sedangkan sisanya sebesar 29\% dijelaskan oleh variabel lain yang tidak dimasukkan ke dalam model.

Nilai F-hit sebesar 41,670 menunjukkan bahwa variabel motivasi, kemampuan, kedinamisan, keberdayaan, lingkungan sosial budaya, kinerja penyuluhan, dan partisipasi secara simultan berpengaruh signifikan terhadap kemandirian petani kedelai.

Motivasi berpengaruh signifikan terhadap kemandirian petani kedelai. Koefisien regresi bertanda positif menunjukkan bahwa semakin tinggi motivasi petani untuk menjalankan usahatani kedelai, maka akan semakin tinggi pula tingkat kemandirian petani kedelai. Hal ini sejalan dengan hasil penelitian Pata (2019) dan Djuliansah dkk (2020) yang menyebutkan bahwa motivasi petani sangat berperan dan berpengaruh terhadap suksesnya usahatani kedelai.

Kemampuan petani berpengaruh signifikan terhadap kemandirian petani kedelai. Koefisien regresi bertanda positif menunjukkan bahwa semakin tinggi kemampuan petani untuk menjalankan usahatani kedelai, maka akan semakin tinggi pula tingkat kemandirian petani kedelai. Artinya, dalam keadaan sewajarnya, petani tidak akan melakukan hal-hal di luar kemampuannya atau yang merugikan dirinya. Kemampuan petani berkaitan dengan situasi lingkungan serta keadaan yang melekat pada dirinya (Zakaria, 2010).

Kedinamisan petani tidak berpengaruh signifikan terhadap kemandirian petani kedelai. Koefisien regresi bertanda positif menunjukkan bahwa semakin tinggi kedinamisan petani untuk menjalankan usahatani kedelai, maka akan semakin tinggi pula tingkat kemandirian petani kedelai. Fakta lapangan menunjukkan bahwa sebagian petani melakukan kolaborasi pengetahuan lokal dengan teknologi anjuran pemerintah dalam melaksanakan usahatani kedelai. Namun, di sisi lain petani yang relatif tua lebih sering menggunakan teknologi-teknologi sederhana yang kerap dipakai orang tua zaman dahulu dalam melaksanakan usahatani kedelai. Penggunaan teknologi sederhana warisan orang tua zaman dahulu tersebut membuat petani cenderung tidak dinamis dalam mengikuti perkembangan teknologi 
budidaya kedelai. Narwoko (2007) menyebutkan bahwa kehidupan manusia tidak statis tetapi akan selau berubah (dinamis). Oleh karena itu, seorang petani harus proaktif serta tidak alergi dengan perubahan di dunia luar. Semakin dinamis perilaku seorang petani maka semakin terbuka pengetahuan dan wawasannya untuk meraih kesuksesan dalam usahataninya.

Keberdayaan petani berpengaruh signifikan terhadap kemandirian petani kedelai. Koefisien regresi bertanda positif menunjukkan bahwa semakin tinggi keberdayaan petani untuk menjalankan usahatani kedelai, maka akan semakin tinggi pula tingkat kemandirian petani kedelai. Wrihatnolo (2007) menyebutkan bahwa keberdayaan masyarakat adalah unsur-unsur yang memungkinkan masyarakat untuk bertahan (survive). Petani kedelai di Kecamatan Jatiwaras sebagian besar mampu mandiri dengan segala keterbatasannya dalam menjalankan usahatani kedelai. mereka memanfaatkan segala sumber daya yang ada di sekitar lahan usahatani dan mengoptimalkannya untuk menghindari kerugian usahatani kedelai.

Lingkungan sosial budaya petani kedelai di Kecamatan Jatiwaras berpengaruh signifikan terhadap kemandirian petani kedelai. Koefisien regresi bertanda positif menunjukkan bahwa semakin tinggi lingkungan sosial budaya petani kedelai, maka akan semakin tinggi pula tingkat kemandirian petani kedelai. Amanah dkk (2008) menyebutkan bahwa aspek lingkungan sosial budaya sangat berperan penting dalam pengambilan keputusan petani pada, setiap kegiatan usahataninya. Artinya petani kedelai di Kecamatan Jatiwaras memiliki lingkungan sosial budaya yang mendukung untuk terselenggaranya usahatani kedelai yang berkelanjutan. Terbukti dengan penetapan Kecamatan Jatiwaras sebagai daerah potensial peningkatan produksi kedelai Provinsi Jawa Barat.

Kinerja penyuluhan berpengaruh signifikan terhadap kemandirian petani kedelai. Koefisien regresi bertanda positif menunjukkan bahwa semakin tinggi kinerja penyuluhan, maka akan semakin tinggi pula tingkat kemandirian petani kedelai. Fakta lapangan menunjukkan bahwa kinerja penyuluhan di Kecamatan Jatiwaras kurang optimal yang disebabkan intensitas penyuluh datang ke lahan petani sangat kurang. Padahal Suwanti dkk (2019) menyebutkan bahwa kinerja penyuluh yang baik akan sangat membantu petani dalam mengembangkan 
usahataninya sehingga ke depan petani mampu dan mandiri melaksanakan usahatani kedelai.

Partisipasi petani kedelai di Kecamatan Jatiwaras berpengaruh signifikan terhadap kemandirian petani kedelai. Koefisien regresi bertanda positif menunjukkan bahwa semakin tinggi partisipasi petani kedelai, maka akan semakin tinggi pula tingkat kemandirian petani kedelai. Partisipasi petani kedelai di Kecamatan Jatiwaras dapat dilihat dari intensitas keikutsertaan dalam setiap kegiatan kelompok tani. Dimana dalam kegiatan kelompok tani tersebut sebagai sarana tukar informasi dan pengetahuan terkait usahatani kedelai yang dijalankan.

Sharing dalam kegiatan tersebut pada akhirnya akan membuat perubahan perilaku petani menuju ke arah kemandirian. Seperti yang diungkapkan Sadono dan Budiman (2010) bahwa partisipasi petani dalam suatu kegiatan pemberdayaan (kegiatan kelompok tani) merupakan suatu langkah untuk mencapai kemandirian petani.

\section{KESIMPULAN DAN SARAN}

Hasil penelitian menunjukan bahwa: (1) tingkat kemandirian petani kedelai di Kecamatan Jatiwaras termasuk kategori sedang (58 persen) (2) motivasi, kemampuan, lingkungan sosial budaya, kinerja penyuluhan, keberdayaan, dan partisipasi berpengaruh signifikan terhadap kemandirian petani kedelai, sedangkan kedinamisan tidak berpengaruh signifikan.

Upaya peningkatan kemandirian petani kedelai dapat ditempuh melalui kegiatan pemberdayaan yang terintegrasi antar stakeholder (penyuluh, petani, pelaku usaha) dengan bimbingan teknis atau pendampingan yang intensif. Sehingga diharapkan petani mampu secara mandiri melaksanakan usahatani kedelai dan mendapatkan hasil yang optimal demi tercapainya tingkat kesejahteraan petani kedelai.

\section{DAFTAR PUSTAKA}

Amanah, S. Hastuti, E,L. Basuno, E. (2008). Aspek Sosial Budaya dalam Penyelenggaraan Penyuluhan: Kasus Petani di Lahan Marjinal. Jurnal Transdisiplin Sosiologi, Komunikasi, dan Ekologi Manusia, Desember 2008.

Apriantono, A. (2006). Pembangunan Pertanian di Indonesia. Departemen Pertanian. Jakarta.

Budiman, M. F., \& Sadono, D. (2010). Tingkat Partisipasi dan Kemandirian Petani Alumni Sekolah Lapangan Pengelolaan Tanaman Terpadu (Kasus Desa Kebon Pedes, Kecamatan Kebon Pedes, Kabupaten Sukabumi, Provinsi Jawa Barat). Jurnal Penyuluhan, 6(2), 8566. 
Departemen Pengembangan Akses Keuangan dan UMKM. (2013). Pola Pembiayaan Usaha Kecil Menengah Usaha Budidaya Kedelai. Bank Indonesia.

Djuliansah, Dedi, Trisna Insan Noor, Yosini Deliana, Meddy Rachmadi. (2020). Faktor-Faktor yang Berpengaruh Terhadap Tingkat Kemandirian Petani Kedelai di Kecamatan Pancatengah Kabupaten Tasikmalaya. Mimbar Agribisnis, 6(2), (2020).

Ethridge, Don. (2004). Research Methodology in Applied Economics (2nd edition). IOWA: Blackwell Publishing.

Hasan, Nur, et a. (2015). Analysis of Soybean Production and Demand to Develop Strategic Policy of Food Self Sufficiency: A System Dynamics Framework. Procedia Computer Science, 72, pp. 605-612.

Indraningsih, K.S. (2013). Faktor-faktor yang mempengaruhi kinerja usahatani petani sebagai representasi strategi penyuluhan pertanian berkelanjutan di lahan marjinal. Jurnal Agroekonomi, 31(1): 71-95.

Kementerian Pertanian. (2019). Outlook Kedelai tahun 2018. Pusat data dan sistem Informasi. Kementerian Pertanian. Jakarta.

Krisnawati, Ayda. (2017). Kedelai sebagai Pangan Fungsional. Jurnal Iptek Tanaman Pangan, 12(1), 2017.

Marliati, Sumardjo, Pang S. Asngari, Prabowo Tjitropranoto, dan Asep Saefuddin. (2010). Faktor-Faktor yang Berpengaruh terhadap Kemandirian Petani Tanaman Pangan Beragribisnis di Kabupaten Kampar, Provinsi Riau. Jurnal Forum Pascasarjana, 33(3): 221228
Marwoto, A. Taufiq, dan Suyamto. (2012). Potensi Pengembangan Tanaman Kedelai di Perkebunan Kelapa Sawit. Jurnal Litbang Pertanian, 31(4): 169-174.

Mugniesyah, S.S.M. (2006). Materi Bahan Ajar Ilmu Penyuluhan. Departemen Sains Komunikasi dan Pengembangan Masyarakat. Fakultas Ekologi Manusia. Institut Pertanian Bogor. Tidak dipublikasikan.

Mun'im, A. (2012). Analisis faktor ketersediaan, akses dan penyerapan pangan di kabupaten surplus pangan: Pendekatan Partial Least Square Path Modelling. Jurnal Agroekonomi. 30(1): 41-56.

Narwoko, J. Dwi \& Suyanto, Bagong. (2007). Sosiologi: Teks Pengantar \& Terapan. Jakarta: Kencana Prenada Media.

Pata, Abdul. (2019). Kontribusi Usahatani Kedelai Terhadap Pendapatan Petani (Studi Kasus di Desa Sambueja Kecamatan Simbang Kabupaten Maros). AGROVITAL: Jurnal Ilmu Pertanian 4(2):47

Sudaryanto, Tahlim dan Swastika, Dewa K.S. (2013). Ekonomi Kedelai di Indonesia. Pusat Penelitian dan Pengembangan Tanaman Pangan. Kementerian Pertanian.

Sumarlan, Sumardjo, Prabowo, T., dan Darwis, S. (2012). Peningkatan kinerja petani sekitar hutan dalam penerapan sistem agroforestry di pegunungan Kendeng Pati. Jurnal Agroekonomi. 30(1): 25-39.

Suwanti, V. Kasimin, S. dan Ismayani. 2019. Analisis Kinerja Penyuluh Pertanian Pada Program Upaya Khusus (Upsus) Peningkatan Produksi Padi, Jagung Dan Kedelai Di Kabupaten Aceh Besar. Jurnal AGRIFO, 4(1), April 2019. 
Wrihatnolo, Randy R. (2007). Manajemen Pemberdayaan: Sebuah Pengantar dan Panduan untuk Pemberdayaan Masyarakat. Jakarta: PT Elex Komputindo.

Wulanjari, Munir Eti dan Setiani, Cahyati. (2018). Strategi Pemberdayaan Petani dalam Berusahatani. Prosiding Seminar Nasional Universitas Muhammadiyah Purwokerto 2018.
Zakaria, Amar K. (2010). Program Pengembangan Agribisnis Kedelai Dalam Peningkatan Produksi dan Pendapatan Petani. Jurnal Litbang Pertanian, 29(4), 2010. 